\title{
Impacts of Climate Change on Food Production and On
}

\section{the Agricultural Environment}

Daniele De Wrachien

Senior Professor Department of Agricultural and Environmental Sciences, Milan University, Italy, Past President EurAgEng

Corresponding Author: Daniele De Wrachien, Senior Professor Department of Agricultural and Environmental Sciences, Milan University, Italy, Past President EurAgEng.

Received Date: December 07, 2020; Accepted Date: December 10, 2020; Published Date: December 17, 2020

Citation: Daniele De Wrachien (2020) Impacts of Climate Change on Food Production and On the Agricultural Environment. J. Nutrition and Food Processing 3(3); DOI:10.31579/2637-8914/033

Copyright: ( 2020 Daniele De Wrachien, This is an open-access article distributed under the terms of the Creative Commons Attribution License, which permits unrestricted use, distribution, and reproduction in any medium, provided the original author and source are credited.

\begin{abstract}
Despite the enormous advances in our ability to manage the natural world, we have reached the 21 st century in awesome ignorance of what is likely to unfold in terms of both the climate changes and the human activities that affect the environment and the responses of the Earth to these stimuli.

Globally the prospects of increasing the gross cultivated area are limited by the decease of economically attractive sites for large-scale irrigation and drainage projects. Therefore, increase in food production will necessarily rely on a more accurate application of the crop water requirements on the one hand, and modernization and improvement of irrigation and drainage systems on the other hand. These issues have to be analysed in light of the expected impacts of climate change and environmental sustainability.

The present Editorial analyses the relevant aspects of these issues in light of the need to increase food production and for sustainable agricultural environment.

Keywords: agricultural environment; food production.
\end{abstract}

\section{Introduction}

Irrigated agriculture is expected to play a major role in reaching the broader development objectives of achieving food security and improvements in the quality of life, while conserving the environment, in both the developed and developing countries. Especially as we are faced with the prospect of global population growth from almost 6 billion today to at least 8 billion by 2025[1].

In this context, the prospects of increasing the gross cultivated area, in both the developed and developing countries, are limited by the dwindling number of economically attractive sites for new large- scale irrigation and drainage projects. Therefore, any increase in agricultural production will necessarily rely largely on a more accurate estimation of crop water requirements on the one hand, and on major improvements in the operation, management and performance of existing irrigation and drainage systems, on the other.

Concerning agricultural development, most of the world's 270 million ha of irrigated land and 130 million ha of rainfed land with drainage facilities were developed on a step-by-step basis over the centuries. In many of the systems structures have aged or are deteriorating. Added to this, the systems have to withstand the pressures of changing needs, demands and social and economic evolution. Consequently, the infrastructure in most irrigated and drained areas needs to be renewed or even replaced and thus redesigned and rebuilt, in order to achieve improved sustainable production. This process depends on a number of common and well-coordinated factors, such as new and advanced technology, environmental protection, institutional strengthening, economic and financial assessment, research thrust and human resource development.

All the above factors and constraints compel decision-makers to review the strengths and weaknesses of current trends in irrigation and drainage and rethink technology, institutional and financial patterns, research thrust and manpower policy, so that service levels and system efficiency can be improved in a sustainable manner [2].

\section{Food Production and Agricultural Environment}

Over the last forty years, the irrigation has been a major contributor to the growth of food and fiber supply for a global population that has more than doubled, from 3 to over 6 billion people. Global irrigated area increased by around $2 \%$ a year in the 1960 s and 1970 s, slowing down to around $1 \%$ in the 1980s, and lower still in the 1990s. Between 1965 and 1995 the world's irrigated land grew from 150 to 260 million ha. Nowadays it is increasing at a very slow rate because of the significant slowdown in new investments, combined with the loss of irrigated areas due to salinization and urban encroachment.

Notwithstanding these achievements, today the majority of agricultural land (1.1 billion ha) still has no water management system. In this context it is expected that $90 \%$ of the increase in food production will have to come from existing cultivated land and only $10 \%$ from conversion from other uses. In the rainfed areas with no water 
management systems some improvements can be achieved with water harvesting and watershed management. However, in no way can the cultivated area with no water management contribute significantly to the required increase in food production. For this reason, the share of irrigated and drained areas in food production will have to increase. This can be achieved either by installing irrigation or drainage facilities in the areas without a system or by improving and modernizing existing systems. The International Commission on Irrigation and Drai- nage (ICID) estimates that within the next 25 years, this process may result in a shift of the contribution to the total food production to around $30 \%$ for the areas with no water management system, $50 \%$ for the areas with an irrigation system and $20 \%$ for the rainfed areas with a drainage system [3].

\section{Climate Change Scenarios}

Scenarios are "internally-consistent pictures of a plausible future climate" [4]. These scenarios can be classified into three groups:

- hypothetical scenarios;

- climate scenarios based on General Circulation Models (GCMs);

- Scenarios based on reconstruction of warm periods in the past (paleo-climatic reconstruction).

The plethora of literature on this topic has been recently summarized by the Intergovernmental Panel on Climate Change [5].

The scenarios of the second group have been widely utilized to reconstruct seasonal conditions of the change in temperature, precipitation and potential evapotraspiration at basin scale over the next century. GCMs are complex three-dimensional computer-based models of the atmospheric circulation, which provide details of changes in regional climates for any part of the Earth. Until recently, the standard approach has been to run the model with a nominal "pre-industrial" atmospheric carbon dioxide ( $\left.\mathrm{CO}_{2}\right)$ concentration (the control run) and then to rerun the model with doubled (or sometimes quadrupled) $\mathrm{CO}_{2}$ (the perturbed run). This approach is known as "the equilibrium response prediction". The more recent and advanced GCMs are, nowadays, able to take into account the gradual increase in the $\mathrm{CO}_{2}$ concentration through the perturbed run. However, current results are not sufficiently reliable.

\section{Planning and Design of Irrigation and Drainage Systems under Climate Change}

Uncertainties as to how the climate will change and how irrigation and drainage systems will have to adapt to these changes, are challenges that planners and designers will have to cope with. In view of these uncertainties, planners and designers need guidance as to when the prospect of climate change should be embodied and factored into the planning and design process.

If climate change is recognized as a major planning issue (first step), the second step in the process would consist of predicting the impacts of climate change on the region's irrigated or drained area. The third step involves the formulation of alternative plans, consisting of a system of structural and/or non-structural measures and hedging strategies that address, among other concerns, the projected consequences of climate change. Non-structural measures that might be considered include modification of management practices, regulatory and pricing policies. Evaluation of the alternatives, in the fourth step, would be based on the most likely conditions expected to exist in the future with and without the plan [6]. The final step in the process involves comparing the alternatives and selecting a recommended development plan.

The main factors that might influence the worth of incorporating climate change into the analysis are the level of planning (local, national, international), the reliability of GCMs, the hydrologic conditions, the time horizon of the plan or life of the project[7] [8][9].

\section{Concluding Remarks}

$>\quad$ Most of the world's irrigation and drainage facilities were developed on a step-by-step basis over the centuries and were designed for a long life (50 years or more), on the assumption that climatic conditions would not change in the future. This will not be so in the years to come, due to global warming and the greenhouse effect. Therefore, engineers and decision-makers need to systematically review planning principles, design criteria, operating rules, contingency plans and water management policies.

$>\quad$ Possible impacts of climate variability that may affect planning principles and design criteria include changes in temperature, precipitation and runoff patterns, sea level rise, flooding of coastal irrigated and rainfed lands.

$>\quad$ Uncertainties as to how the climate will change and how irrigation and drainage systems will have to adapt to these changes are issues that water authorities are compelled to cope with. The challenge is to identify short-term strategies to face long-term uncertainties. The planning and design process needs to be sufficiently flexible to incorporate consideration of and responses to many possible climate impacts. The main factors that will influence the worth of incorporating climate change into the process are the level of planning, the reliability of the forecasting models, the hydrological conditions and the time horizon of the plan or the life of the project.

$>\quad$ The development of a comprehensive approach that integrates all these factors into irrigation and drainage project selection, requires further research of the processes governing climate changes, the impacts of increased atmospheric carbon dioxide on vegetation and runoff, the effect of climate variables on water demand for irrigation and the impacts of climate on infrastructure performance.

\section{References}

1. De Wrachien D., Feddes R. (2003) Drainage and Land Reclamation in a Changing Environment: Overview and Challenges. Opening Address. Proceeding of the International Conference on Land Reclamation and Water resources Development. Mantua, Italy

2. De Wrachien D., Goli M.(2015) Global Warming Effects on Irrigation Development and Crop Production . A World-wide View. Agricultural Sciences ,6,7

3. Schultz B. and De Wrachien D. (2002) Irrigation and Drainage Systems. Research and Development in the 21st Century. Irrigation and Drainage, 51, 311-327

4. Wigley, T.M.L., Jones, P.D. and Kelly, P.M. (1986) Empirical Climate Studies. Warm World Scenarios and the Detec- tion of Climate Change Induced by Radioactively Active Fases. In: Bolin, B., Doos, B.R., Jager, J. and Warrich, R.A., Eds., The Greenhouse Effect, Climatic Change and Ecosystems, SCOPE 26, Wiley Publisher, New York, 271-322

5. Scott, D.B. and Collins, E.S. (1996) Late Mid-Holocene SeaLevel Oscillation: A Possible Cause. Quaternary Science Reviews, 15, 851-856

6. Reed, M.S., Fraser, E.D.G. and Dougill, A.J. (2006) An Adaptive Learning Process for Developing and Applying Sustainability Indicators with Local Communitis , Ecological Economics, 59 ,406-418 
7. ICID (2015). Report on the Consultative Group on ICID Vision 2030.

8. Arora N.K.( 2019). Impact of Climate Change on Agriculture Production and its sustainable Solutions .Environmental Sustainability 2, 95-96
9. Bruce M.,Campbell ,Sonja J. Vermeulen , Pramod K. Aggarwal, et al (2016). Reducing Risk to Food Security from Climate Change. Global Food Security. Volume 11, 2016, 3443.
This work is licensed under Creative

Commons Attribution 4.0 License

To Submit Your Article Click Here: Submit Manuscript

DOI:10.31579/2637-8914/033
Ready to submit your research? Choose Auctores and benefit from:

* fast, convenient online submission

* rigorous peer review by experienced research in your field

* rapid publication on acceptance

* authors retain copyrights

* unique DOI for all articles

* immediate, unrestricted online access

At Auctores, research is always in progress.

Learn more https://www.auctoresonline.org/journals/nutrition-and-foodprocessing 